\title{
KEMAMPUAN MENGONTROL DIRI MAHASISWA KEDOKTERAN DALAM BELAJAR, PENGERJAAN TUGAS, DAN PENGGUNAAN GAWAI
}

\author{
Christy $^{1}$, Riana Sahrani ${ }^{2}$, Pamela Hendra Heng ${ }^{3}$ \\ ${ }^{1}$ Program Studi Magister Psikologi Profesi, Universitas Tarumanagara, Jakarta \\ Email: christy.717172019@stu.untar.ac.id \\ ${ }^{2}$ Fakultas Psikologi, Universitas Tarumanagara, Jakarta \\ Email: rianas@fpsi.untar.ac.id \\ ${ }^{3}$ Fakultas Psikologi, Universitas Tarumanagara, Jakarta \\ Email: pamelah@fpsi.untar.ac.id
}

Masuk : 01-04-2020, revisi: 28-04-2020, diterima untuk diterbitkan : 30-04-2020

\begin{abstract}
Academic burnout was a problem in the world of education that was often experienced by medical students. Educational demands and numerous assignments often caused medical students to felt overwhelmed and experience academic burnout. Uniquely, there were previous studies which found that in the midst of high activity, medical students still had time to access their smartphones. When students spend most of their time for smartphone used rather than their daily activities, students will have the potential to experience problematic smartphone used, which could have a negative impact on their study and daily routines. This problem became more interesting to be discussed considering current situation, in which almost everyone had their own smartphone and often relies on the smartphone for information or leisure purposes. This researched was conducted to examine the role of problematic smartphone used on academic burnout in medical students. Quantitative research using convenience sampling method was conducted to answer the question. The participants of this study were 401 medical students. Result showed that problematic smartphone use had a significant role on academic burnout in medical students $(\beta=0.41$, $t=8.84$ ). The result means an increase score on problematic smartphone use will be followed by an increase score on academic burnout, and vice versa.
\end{abstract}

Keywords: academic burnout, problematic smartphone use, medical students

\begin{abstract}
ABSTRAK
Academic burnout merupakan suatu masalah dalam dunia pendidikan yang seringkali dialami oleh mahasiswa kedokteran. Hal ini ditandai dengan rasa kewalahan, sinis, dan rasa tidak mampu untuk menjalani studi. Tuntutan pendidikan dan banyaknya tugas seringkali membuat mahasiswa kedokteran merasa kewalahan dan mengalami academic burnout. Uniknya, terdapat penelitian terdahulu yang menemukan bahwa di tengah kesibukan yang tinggi, mahasiswa kedokteran masih memiliki waktu untuk mengakses atau memainkan gawai yang dimilikinya. Ketika mahasiswa mengakses gawai dengan intensitas dan durasi yang terlalu panjang, mahasiswa akan memiliki potensi untuk mengalami problematic smartphone use, yang dapat memberikan dampak negatif bagi perkuliahan mahasiswa kedokteran. Masalah ini tentunya semakin menarik untuk dibahas mengingat saat ini setiap orang memiliki gawai dan seringkali bergantung pada gawai yang dimiliki untuk kebutuhan informasi ataupun untuk mengisi waktu luang. Penelitian ini dilakukan untuk menguji peran problematic smartphone use terhadap academic burnout pada mahasiswa kedokteran. Penelitian dengan teknik convenience sampling dilakukan untuk menjawab pertanyaan dalam penelitian ini. Partisipan penelitian ini adalah 401 mahasiswa kedokteran. Hasil penelitian menunjukkan bahwa problematic smartphone use memiliki peran signifikan terhadap academic burnout pada mahasiswa kedokteran $(\beta=0.41, \mathrm{t}=8.84)$. Hal ini berarti peningkatan skor problematic smartphone use akan diikuti dengan peningkatan skor academic burnout mahasiswa kedokteran. Sebaliknya, penurunan skor problematic smartphone use akan diikuti juga dengan penurunan skor academic burnout mahasiswa kedokteran.
\end{abstract}

Kata Kunci: academic burnout, problematic smartphone use, mahasiswa kedokteran

\section{PENDAHULUAN}

Mahasiswa kedokteran dikenal sebagai mahasiswa dengan tuntutan pendidikan yang berat dan tugas praktik yang memiliki standar tinggi (Iorga et al., 2018). Materi kuliah yang diajarkan dalam Fakultas Kedokteran biasanya diberikan dalam bentuk blok, yang setiap bloknya terdapat 
ujian sebagai standar pemahaman dan kelulusan terhadap materi yang dipelajari (Pratiwi \& Elvandari, 2016). Padatnya jadwal kuliah dan banyaknya materi yang perlu dipelajari membuat mahasiswa kedokteran seringkali menghadapi tekanan yang berat dan memiliki waktu istirahat yang minim, sehingga mahasiswa kedokteran pun rentan mengalami burnout (Ball \& Bax dalam Wolf \& Rosenstock, 2016; Yudhistira, 2018).

Penelitian yang telah dilakukan oleh peneliti sebelumnya menunjukkan burnout dalam ranah pendidikan lebih banyak ditemukan pada mahasiswa kedokteran. Di Amerika, Wolf dan Rosenstock (2016) menemukan bahwa 22.4\% mahasiswa kedokteran tahun pertama dan $19.2 \%$ mahasiswa tahun kedua memiliki potensi yang tinggi untuk mengalami burnout. Chunming, Harrison, MacIntyre, Travaglia, dan Balasooriya (2017) juga menemukan bahwa potensi burnout mahasiswa kedokteran di China hampir mencapai 50\%. Masalah burnout pada mahasiswa kedokteran juga dialami oleh mahasiswa di Indonesia. Yudhistira (2018) melakukan penelitian di salah satu universitas di Jakarta terhadap 200 mahasiswa, dengan temuan $77.1 \%$ mahasiswa kedokteran memiliki potensi untuk mengalami burnout dan $10.44 \%$ mahasiswa kedokteran mengalami academic burnout yang tinggi.

Burnout pada mahasiswa kedokteran yang dibahas pada paragraf sebelummya dikenal dengan istilah academic burnout. Academic burnout ditandai dengan exhaustion, yang merupakan kelelahan emosional yang dirasakan mahasiswa terhadap kegiatan akademik; cynicism, yang merupakan rasa sinis terhadap materi yang diajarkan dan kegiatan perkuliahan yang diikuti; dan sense of inadequacy, yang merupakan kondisi ketika mahasiswa merasa tidak mampu menjalani kuliah dan mengerjakan tugas-tugasnya (Salmela-Aro et al., 2009).

Academic burnout yang tidak ditangani dengan baik tentunya dapat menyebabkan masalah dalam pendidikan mahasiswa. Masalah yang mungkin muncul karena academic burnout adalah meningkatnya potensi mahasiswa untuk drop out karena rasa sinis terhadap perkuliahan yang dijalani (Walburg, 2014). Selain itu, academic burnout yang tidak ditanggulangi dengan baik juga dapat memengaruhi profesionalitas kerja lulusan kedokteran ketika menjadi dokter (Wolf \& Rosenstock, 2016). Academic burnout yang berkepanjangan terbukti dapat mengganggu kinerja dan menurunkan ketertarikan individu pada pendidikan di tingkat yang lebih lanjut (Walburg, 2014). Academic burnout juga ditemukan menjadi salah satu prediktor gejala-gejala depresi pada pelajar (Salmera-Aro, Savolainen, \& Holopainen dalam Walburg, 2014).

Salah satu faktor yang memengaruhi academic burnout adalah kemampuan mahasiswa untuk mengatur prioritas belajar dan pengerjaan tugas-tugasnya (Maslach \& Leiter dalam Aydemir \& Icelli, 2013). Di era digital saat ini, pengaturan mahasiswa terhadap proses belajar dan pengerjaan tugas-tugasnya seringkali terganggu karena penggunaan gawai (Ching et al., 2015). Walaupun gawai dapat membantu proses komunikasi dan pencarian informasi (Ching et al., 2015), penggunaan gawai dengan durasi dan intensitas yang berlebihan tentunya dapat mengganggu aktivitas mahasiswa sehari-hari (Kwon, Kim, Cho, \& Yang, 2013).

Penggunaan gawai yang berlebihan sehingga mengganggu aktivitas sehari-hari disebut dengan problematic smartphone use (Kwon, Kim et al., 2013). Ketika mahasiswa mengalami problematic smartphone use, mahasiswa akan mengalami gangguan pada aktivitas sehari-hari, merasa tidak nyaman ketika dirinya tidak berada dekat dengan gawai miliknya, lebih senang berelasi di dunia maya daripada dunia nyata, dan adanya kesulitan untuk menghentikan penggunaan gawai miliknya (Kwon, Lee et al., 2013). 
Problematic smartphone use tentunya memberikan dampak negatif bagi mahasiswa. Dampak negatif yang dapat muncul karena penggunaan gawai yang berlebihan adalah gangguan kesehatan dan kesulitan untuk mengontrol penggunaan gawai (Kwon, Lee et al., 2013). Problematic smartphone use juga dapat mengakibatkan adanya penurunan pada prestasi akademik dan peningkatan stres mahasiswa, karena waktu yang seharusnya digunakan untuk belajar dihabiskan untuk mengakses dan memainkan gawai (Samaha \& Hawi, 2016). Waktu yang kurang untuk belajar tersebut kemudian dapat menyebabkan mahasiswa mengalami work overload. Siklus yang berulang antara penggunaan gawai yang berlebihan dan penumpukan tugas-tugas yang tak kunjung selesai kemudian akan memicu terjadinya academic burnout (Elhai, Dvorak, Levine, \& Hall, 2017).

Berdasarkan paparan permasalahan dan hasil penelitian sebelumnya, peneliti menemukan bahwa academic burnout merupakan suatu permasalahan yang serius dan perlu ditanggulangi, terutama pada mahasiswa kedokteran yang kelak akan menjalani profesi sebagai dokter dan melayani masyarakat. Hasil penelitian sebelumnya masih menunjukkan persentase academic burnout yang berbeda-beda pada mahasiswa kedokteran (Wolf \& Rosenstock, 2016; Chunming et al., 2017; Yudhistira, 2018). Selain itu, dampak kegunaan gawai dalam kalangan mahasiswa belum diketahui dengan jelas, karena gawai dapat berfungsi untuk membantu proses pencarian informasi (Chunming et al., 2017). Namun, di sisi lain penggunaan gawai yang berlebihan dapat menyebabkan gangguan aktivitas belajar mahasiswa (Kwon, Kim et al., 2013). Penelitian ini juga hendak mempertegas keterkaitan antara problematic smartphone use dengan academic burnout dengan melakukan uji peran. Dengan demikian, permasalahan dalam penelitian ini adalah "Apakah terdapat peran problematic smartphone use dengan academic burnout mahasiswa kedokteran?"

Berdasarkan rumusan masalah, kajian teori variabel-variabel penelitian, dan hasil penelitian sebelumnya, hipotesis penelitian ini adalah terdapat peran problematic smartphone use terhadap academic burnout pada mahasiswa kedokteran.

\section{METODE PENELITIAN}

Desain penelitian ini merupakan penelitian kuantitatif korelasional yang dilakukan untuk mengetahui peran problematic smartphone use terhadap academic burnout mahasiswa kedokteran.

Partisipan dalam penelitian ini adalah mahasiswa kedokteran yang sedang menjalani kuliah pada program studi sarjana kedokteran di Jakarta, memiliki setidaknya satu buah gawai, dan merupakan pengguna gawai. Partisipan tidak dibatasi oleh jenis kelamin, agama, suku, ataupun ras. Jumlah partisipan dalam penelitian ini adalah 401 orang, yang terdiri dari 108 laki-laki dan 293 perempuan. Partisipan dalam penelitian ini berusia 18 sampai dengan 25 tahun $(M=20.18$, $\mathrm{SD}=1.03)$. Teknik sampling yang digunakan dalam penelitian ini adalah convenience sampling method. Dengan teknik sampling tersebut, partisipan dipilih berdasarkan ketersediaan dan kesediaan mahasiswa kedokteran untuk berpartisipasi dalam penelitian ini (Trochim, Donnnelly, \& Arora, 2016).

Pengumpulan data pada penelitian ini dilakukan melalui kuesioner yang diisi oleh partisipan. Kuesioner yang diberikan terdiri dari empat bagian, yaitu bagian persetujuan untuk terlibat sebagai partisipan (informed consent), identitas diri, kuesioner untuk mengukur problematic smartphone use, dan kuesioner untuk mengukur academic burnout. 
Variabel dalam penelitian ini terdiri dari satu variabel independen dan satu variabel dependen. Variabel independen pada penelitian ini adalah problematic smartphone use, yang secara operasional didefinisikan sebagai suatu kondisi ketika mahasiswa kedokteran memiliki keinginan untuk mengakses gawai terus-menerus dan mengganggu proses belajar serta pengerjaan tugasnya. Problematic smartphone use merupakan variabel unidimensi yang diukur dengan Smartphone Addiction Scale Short Version (SAS-SV). Alat ukur ini dikembangkan oleh Kwon, Kim et al. (2013). SAS-SV terdiri dari 10 pernyataan positif (contoh: "Saya melewatkan pekerjaan yang sudah saya rencanakan karena penggunaan gawai"). Butir-butir pernyataan tersebut yang telah melalui proses adaptasi ke dalam bahasa Indonesia dan uji pakar terkait validitas konten, serta telah melalui proses face validity oleh mahasiswa kedokteran dalam proses uji coba alat ukur. Alat ukur ini menggunakan skala Likert dengan 6 pilihan jawaban $(1=$ sangat tidak setuju sampai 6 = sangat setuju). Alat ukur SAS-SV memiliki Alpha Cronbach sebesar 0.911 .

Variabel dependen pada penelitian ini adalah academic burnout, yang secara operasional didefinisikan sebagai kondisi lelah dengan tuntutan akademik, sinis dan menarik diri dari proses belajar dan mengerjakan tugas, serta perasaan tidak mampu untuk menjalani kuliah sebagai mahasiswa kedokteran. Academic burnout terdiri dari tiga dimensi, yaitu exhaustion, cynicism, dan sense of inadequacy. Alat ukur yang digunakan dalam penelitian ini adalah School Burnout Inventory (SBI) yang dikembangkan oleh Salmela-Aro, Kiuru, Leskinen, dan Nurmi (2009). SBI terdiri dari 9 pernyataan positif, yang dibagi dalam empat pernyataan untuk mengukur dimensi exhaustion (contoh: "Saya merasa sangat lelah mengerjakan tugas kuliah yang ada"), tiga pernyataan untuk mengukur dimensi cynicism (contoh: "Motivasi saya untuk kuliah menurun dan seringkali terpikir untuk menyerah saja"), dan 2 pernyataan untuk mengukur dimensi sense of inadequacy (contoh: "Saya seringkali merasa tidak mampu menjalani kuliah ini"). SBI telah diadaptasi ke dalam bahasa Indonesia dan telah melalui proses uji pakar terkait validitas konten dan face validity oleh mahasiswa kedokteran dalam proses uji coba alat ukur. Alat ukur ini menggunakan skala Likert dengan 6 pilihan jawaban $(1=$ sangat tidak setuju sampai $6=$ sangat setuju). Alat ukur SBI memiliki Alpha Cronbach sebesar 0.626 untuk dimensi exhaustion, 0.782 untuk dimensi cynicism, dan 0.704 untuk dimensi sense of inadequacy.

Penelitian ini bertujuan menguji peran problematic smartphone use terhadap academic burnout. Teknik analisis yang digunakan dalam penelitian ini adalah analisis regresi linear dengan program SPSS versi 23. Sebelum melakukan analisis, peneliti akan melakukan uji normalitas dan uji linearitas terlebih dahulu untuk mengetahui kondisi sebaran data dan untuk memenuhi persyaratan dilakukannya analisis regresi linear.

\section{HASIL DAN PEMBAHASAN}

Hasil analisis deskriptif terhadap variabel problematic smartphone use dan academic burnout disajikan pada tabel 1. Kondisi problematic smartphone use dan academic burnout dibagi ke dalam dua kategori, yaitu kategori rendah dan tinggi. Kategori rendah akan diberikan pada partisipan yang memiliki skor di bawah rerata hipotetik, sedangkan kategori tinggi akan diberikan pada partisipan yang memiliki skor sama dengan atau lebih tinggi daripada rerata hipotetik.

Berdasarkan hasil analisis deskriptif, terdapat 232 partisipan yang memiliki kecenderungan problematic smartphone use yang rendah (57.9\%) dan 169 partisipan yang memiliki kecenderungan problematic smartphone use yang tinggi $(42.1 \%)$. Rerata empirik problematic smartphone use pada penelitian ini adalah 3.30, sedangkan rerata hipotetik problematic 
smartphone use adalah 3.50. Dengan demikian, secara keseluruhan dapat dikatakan bahwa partisipan memiliki skor problematic smartphone use yang tergolong rendah.

Analisis deskriptif juga dilakukan terhadap variabel academic burnout. Berdasarkan hasil pengolahan data yang dilakukan, terdapat 293 partisipan yang memiliki skor academic burnout yang rendah (73.1\%) dan 108 partisipan yang memiliki skor academic burnout tinggi (26.9\%). Rerata empirik academic burnout pada penelitian ini adalah 3.00, sedangkan rerata hipotetik academic burnout adalah 3.50. Dengan demikian, secara keseluruhan dapat dikatakan bahwa partisipan memiliki skor academic burnout yang tergolong rendah.

\section{Tabel 1. Data Deskriptif Problematic Smartphone Use dan Academic Burnout:}

\begin{tabular}{|c|c|c|c|c|c|c|}
\hline \multirow{2}{*}{ Variabel } & \multirow{2}{*}{ Kategori } & \multirow{2}{*}{ Jumlah } & \multirow{2}{*}{$\begin{array}{c}\text { Persentase } \\
(\%)\end{array}$} & \multicolumn{2}{|c|}{ Mean } & \multirow{2}{*}{$\begin{array}{l}\text { Standar } \\
\text { Deviasi }\end{array}$} \\
\hline & & & & Empirik & Hipotetik & \\
\hline \multirow{2}{*}{$\begin{array}{c}\text { Problematic } \\
\text { Smartphone } \\
\text { Use }\end{array}$} & Rendah & 232 & 57.9 & \multirow{2}{*}{3.30} & \multirow{2}{*}{3.50} & \multirow{2}{*}{0.80} \\
\hline & Tinggi & 169 & 42.1 & & & \\
\hline \multirow{2}{*}{$\begin{array}{c}\text { Academic } \\
\text { Burnout }\end{array}$} & Rendah & 293 & 73.1 & \multirow{2}{*}{3.00} & \multirow{2}{*}{3.50} & \multirow{2}{*}{0.82} \\
\hline & Tinggi & 108 & 26.9 & & & \\
\hline
\end{tabular}

Peneliti juga melakukan uji normalitas untuk mengetahui sebaran data yang diperoleh. Berdasarkan hasil uji normalitas, diperoleh bahwa variabel problematic smartphone use terdistribusi normal $(\mathrm{p}=0.998)$. Variabel academic burnout juga terdistribusi normal $(\mathrm{p}=$ 0.998).

Selain melakukan uji normalitas, peneliti juga melakukan uji linearitas terhadap variabel problematic smartphone use dan academic burnout. Berdasarkan hasil uji linearitas, problematic smartphone use dan academic burnout memiliki hubungan yang linear $(\mathrm{F}=0.767$ dan $\mathrm{p}=$ 0.790). Oleh karena itu, analisis regresi linear dapat dilakukan.

Langkah selanjutnya yang peneliti lakukan adalah melakukan analisis regresi linear terhadap problematic smartphone use dan academic burnout. Berdasarkan hasil uji regresi linear, diperoleh hasil bahwa terdapat peran problematic smartphone use yang signifikan terhadap academic burnout pada mahasiswa kedokteran $(\beta=0.41, \mathrm{t}=8.84)$. Hal tersebut berarti, skor problematic smartphone use yang semakin tinggi akan diikuti dengan peningkatan skor academic burnout pada mahasiswa kedokteran. Sebaliknya, skor problematic smartphone use yang semakin rendah akan diikuti dengan penurunan skor academic burnout pada mahasiswa kedokteran.

Hasil penelitian yang menunjukkan bahwa problematic smartphone use memiliki peran terhadap academic burnout pada mahasiswa kedokteran dapat disebabkan karena problematic smartphone use dapat memberikan dampak negatif bagi academic burnout. Hasil ini mendukung penelitian sebelumnya yang juga mengatakan bahwa penggunan gawai yang berlebihan menyebabkan menumpuknya tugas yang terbengkalai dan menyebabkan academic burnout (Elhai et al., 2017). Hasil penelitian ini juga sejalan dengan hasil penelitian sebelumnya yang menemukan bahwa ketika individu asyik mengakses gawai, individu seringkali kehilangan kontrol diri individu, sulit 
melepaskan diri dari penggunaan gawai dan akhirnya mengganggu kesehariannya (Kwon, Lee, et al., 2013). Kesulitan kontrol diri tersebut pun dapat menyebabkan manajemen waktu yang kurang baik dan buruknya kemampuan untuk mengontrol prioritas (Kirana, Sahrani, \& Hastuti, 2016) atau disebut dengan work overload (Derks \& Bakker dalam Elhai et al., 2017), dan menjadi faktor yang dapat memicu terjadinya academic burnout (Maslach \& Leiter dalam Aydemir \& Icelli, 2013).

Penelitian ini juga menunjukkan bahwa problematic smartphone use memberikan peran terhadap academic burnout sebesar $16.4 \%\left(\mathrm{R}^{2}=0.164\right.$, lihat tabel 2$)$. Hal tersebut berarti terdapat faktor lainnya di luar penelitian yang memengaruhi academic burnout. Faktor-faktor di luar problematic smartphone use yang dapat berperan terhadap academic burnout dapat berupa kurangnya apresiasi pendidik terhadap mahasiswa (Maslach \& Leiter dalam Aydemir \& Icelli, 2013), kurangnya dukungan sosial dari lingkungan mahasiswa (Slivar, 2001; Walburg, 2014), dan kecemasan terhadap nilai dan target kuliah (Slivar, 2001).

Tabel 2. Hasil Analisis Regresi Linear Problematic Smartphone Use dan Academic Burnout:

\begin{tabular}{|c|c|c|c|}
\hline Variabel & B & $\mathbf{T}$ & $\mathbf{R}^{2}$ \\
\hline Problematic Smartphone Use & \multirow{2}{*}{0.41} & \multirow{2}{*}{8.84} & \multirow{2}{*}{0.164} \\
\hline Academic Burnout & & & \\
\hline
\end{tabular}

Selanjutnya, peneliti juga melakukan analisis regresi tambahan untuk mengetahui besar peran problematic smartphone use terhadap setiap dimensi academic burnout, yaitu exhaustion, cynicism, dan sense of inadequacy. Analisis tersebut dilakukan dengan melakukan analisis regresi linear, dengan melihat nilai t dari hasil analisis regresi antara problematic smartphone use dengan setiap dimensi academic burnout.

Dimensi pertama yang peneliti uji adalah peran problematic smartphone use terhadap exhaustion. Hasil pengujian menunjukkan $\beta=0.33, \mathrm{t}=6.93$. Dimensi kedua yang peneliti uji adalah peran problematic smartphone use terhadap cynicism. Hasil pengujian menunjukkan $\beta=$ $0.35, \mathrm{t}=7.40$. Dimensi ketiga yang peneliti uji adalah peran problematic smartphone use terhadap academic burnout. Berdasarkan hasil pengujian terhadap ketiga dimensi academic burnout yang telah dilakukan, tampak bahwa problematic smartphone use memberikan peran terbesar pada dimensi sense of inadequacy $(\beta=0.35, \mathrm{t}=7.51)$.

Sesuai dengan definisi yang telah dipaparkan, sense of inadequacy adalah kondisi ketika individu merasa tidak mampu menyelesaikan tugas pendidikannya (Salmela-Aro et al., 2009). Apabila mengacu pada teori mengenai faktor yang memicu terjadinya academic burnout, kontrol diri dan work overload menjadi pemicu terjadinya academic burnout, karena individu mungkin tidak memiliki waktu yang cukup untuk dapat menyelesaikan tugas dan tuntutan belajarnya (Maslach \& Leiter dalam Aydemir \& Icelli, 2013). Sehingga, ketika mahasiswa kedokteran menggunakan gawai secara berlebihan hingga mengganggu dan menyita waktu belajarnya, maka mahasiswa tersebut akan merasa tidak mampu mengontrol dirinya dan tidak mampu menyelesaikan studinya, yang diikuti dengan hasil tugas atau nilai yang kurang maksimal. Hasil pengujian yang lebih jelas dapat dilihat pada tabel 3 di halaman berikutnya. 
Tabel 3. Hasil Analisis Regresi Linear Problematic Smartphone Use dengan Dimensi-Dimensi Academic Burnout:

\begin{tabular}{lcccccc}
\hline & \multicolumn{2}{c}{ Exhaustion } & \multicolumn{2}{c}{ Cynicism } & \multicolumn{2}{c}{ Sense of Inadequacy } \\
\hline & B & t & B & t & B & t \\
\hline $\begin{array}{l}\text { Problematic } \\
\begin{array}{l}\text { Smartphone } \\
\text { Use }\end{array}\end{array}$ & 0.33 & 6.93 & 0.35 & 7.40 & 0.35 & 7.51 \\
\hline
\end{tabular}

\section{KESIMPULAN DAN SARAN}

Penelitian ini dilakukan untuk mengetahui peran problematic smartphone use terhadap academic burnout mahasiswa kedokteran. Pada penelitian ini, hipotesis penelitian terbukti, yang berarti problematic smartphone use memiliki peran terhadap academic burnout mahasiswa kedokteran. Lebih lanjut, problematic smartphone use memberikan peran terbesar terhadap dimensi sense of inadequacy mahasiswa kedokteran. Hal ini dapat disebabkan karena problematic smartphone use dapat mengakibatkan mahasiswa kedokteran merasa dirinya tidak mampu mengontrol dirinya untuk menjalani kuliah dan mengerjakan tugas-tugasnya.

Selain adanya temuan mengenai peran problematic smartphone use terhadap academic burnout, terdapat hal-hal yang perlu diperhatikan untuk menggeneralisasi hasil penelitian ini. Sampel pada penelitian ini diambil dengan teknik convenience sampling pada universitas di Jakarta, sehingga generalisasi perlu dilakukan dengan hati-hati. Uraian mengenai faktor yang paling melelahkan bagi mahasiswa kedokteran juga diperoleh dari jawaban partisipan terhadap pertanyaan yang dicantumkan dalam kuesioner, sehingga jawaban yang diperoleh tidak mendalam seperti informasi yang didapatkan melalui sesi wawancara. Pengambilan data yang berkaitan dengan problematic smartphone use juga memerlukan media untuk mengukur penggunaan gawai dengan lebih akurat, misalnya melalui kerjasama dengan ahli teknologi untuk mengukur penggunaan gawai dengan pemasangan alat pengukur atau penghitung durasi tertentu.

Berdasarkan hasil penelitian dan keterbatasan pada penelitian ini, peneliti menyarankan untuk peneliti berikutnya agar dapat melakukan penelitian yang berfokus pada mahasiswa kedokteran yang memiliki skor academic burnout yang tinggi saja. Penelitian juga dapat dikembangkan untuk menjawab permasalahan di era digital, misalnya mengetahui hubungan academic burnout dengan permasalahan digital yang lebih spesifik, seperti problematic internet use ataupun adiksi media sosial. Peneliti berikutnya juga dapat melakukan penelitian untuk mengetahui faktor lainnya yang berperan terhadap academic burnout, seperti durasi dan kualitas tidur, olahraga, dan relasi dengan sesama teman.

Penelitian untuk mengatasi problematic smartphone use juga perlu dilakukan lebih banyak, karena saat ini kehidupan manusia tampaknya sangat tergantung dengan gawai. Ditambah lagi, saat ini penggunaan gawai tidak hanya terbatas pada usia dewasa, tetapi individu sejak usia dini pun sudah mulai mengakses gawai untuk menonton youtube ataupun bermain game. Transaksi dalam kehidupan sehari-hari pun saat ini sangat bergantung pada gawai, terutama karena kehadiran dompet elektronik. Hal-hal tersebut tentunya menarik untuk diteliti dan dibahas oleh peneliti selanjutnya.

Melalui penelitian ini, peneliti juga memiliki saran bagi mahasiswa kedokteran yang diharapkan dapat membantu mengurangi potensi academic burnout yang dialami. Dengan materi yang sangat banyak dan ujian yang padat, mahasiswa kedokteran diharapkan dapat tetap memprioritaskan waktu belajar dan mencicil materi pelajaran sebelum ujian daripada waktu menggunakan gawai. Apabila merasa kelelahan, mahasiswa kedokteran dapat melakukan 
aktivitas lainnya untuk menenangkan diri, seperti berolahraga, jalan-jalan, atau berbincang dan bertukar pikiran dengan teman-temannya. Kegiatan belajar kelompok juga dapat dilakukan sebagai salah satu alternatif belajar bagi mahasiswa kedokteran untuk mengatasi academic burnout, karena dengan adanya kelompok belajar, akan terbangun pula support system yang dapat menguatkan dan mendukung mahasiswa dalam proses belajar dan menjalani kuliahnya di fakultas kedokteran.

\section{Ucapan Terima Kasih (Acknowledgement)}

Ucapan terima kasih peneliti ucapkan kepada dekan, dosen, staff, dan mahasiswa fakultas kedokteran pada beberapa universitas di daerah Jakarta yang telah memberikan izin untuk pengambilan data penelitian ini. Peneliti juga mengucapkan terima kasih kepada pihak-pihak yang mendukung terlaksananya penelitian dan mempublikasikannya.

\section{REFERENSI}

Aydemir, O., \& Icelli, I. (2013). Burnout: Risk factor. Dalam S. B. Kohler (Ed.), Burnout for experts: Prevention in the context of living and working (pp. 119-124). New York, NY: Springer.

Ching, S. M., Yee, A., Ramachandran, V., Lim, S. M. S., Sulaiman, W. A. W., Foo, Y. L., \& Hoo, F. K. (2015). Validation of a Malay version of the smartphone addiction scale among medical students in Malaysia. PLoS ONE, 10(10), 1-11.

Chunming, W. M., Harrison, R., MacIntyre, R., Travaglia, J., \& Balasooriya, C. (2017). Burnout in medical students: A systematic review of experiences in Chinese medical schools. BMC Medical Education, 17(1), 1-11.

Elhai, J. D., Dvorak, R. D., Levine, J. C., \& Hall, B. J. (2017). Problematic smartphone use: A conceptual overview and systematic review of relations with anxiety and depression psychopathology. Journal of Affective Disorders, 207, 251-259.

Iorga, M., Dondas, C., \& Zugun-Eloae, C. (2018). Depressed as freshmen, stressed as seniors: The relationship between depression, perceived stress and academic results among medical students. Behavioral Sciences, 8(8), 1-12.

Kirana, A., Sahrani, R., \& Hastuti, R. (2016). Intervensi pelatihan self-regulated learning dalam mereduksi prokrastinasi akademik siswa (Studi pada siswa SMPN "X" di Jakarta Barat). Provitae Jurnal Psikologi Pendidikan, 7(1). 20-36.

Kwon, M., Kim, D. J., Cho, H., \& Yang, S. (2013). The smartphone addiction scale: Development and validation of a short version for adolescents. PLOS ONE, 8(12), 1-7.

Kwon, M., Lee, J. Y., Won, W. Y., Park, J. W., Min, J. A., Hahn, C., ... Kim, D. J. (2013). Development and validation of a smartphone addiction scale (SAS). PLOS ONE, 8(2), 17.

Pratiwi, W. M., \& Elvandari, W. (2016). Kuliah jurusan apa? Kedokteran. Jakarta: Gramedia Pustaka Utama.

Salmela-Aro, K., Kiuru, N., Leskinen, E., \& Nurmi, J. E. (2009). School burnout inventory (SBI): Reliability and validity. European journal of psychological assessment, 25(1), 4857.

Samaha, M., \& Hawi, N. S. (2016). Relationships among smartphone addiction, stress, academic performance, and satisfaction with life. Computers in Human Behavior, 57, 321-325.

Slivar, B. (2001). The syndrome of burnout, self-image, and anxiety with grammar school students. Horizons of Psychology, 10(2), 21-32.

Trochim, W., Donnelly, J. P., \& Arora, K. (2016). Research methods: The essential knowledge base ( $2^{\text {nd }}$ ed.). Wadsworth: Cengage. 
Walburg, V. (2014). Burnout among high school students: A literature review. Children and Youth Services Review, 42, 28-33.

Wolf, M. R., \& Rosenstock, J. B. (2016). Inadequate sleep and exercise associated with burnout and depression among medical students. Academic Psychiatry, 41(2). 174-179.

Yudhistira, S. (2018). Peran social support, academic self-efficacy, self-esteem terhadap academic engagement dengan burnout sebagai variabel mediator pada mahasiswa kedokteran (Tesis tidak dipublikasikan). Universitas Tarumanagara, Jakarta. 